ENTREPRENEURSHIP AND SUSTAINABILITY ISSUES

ISSN 2345-0282 (online) http://jssidoi.org/jesi/

2021 Volume 8 Number 4 (June)

http://doi.org/10.9770/jesi.2021.8.4(36)
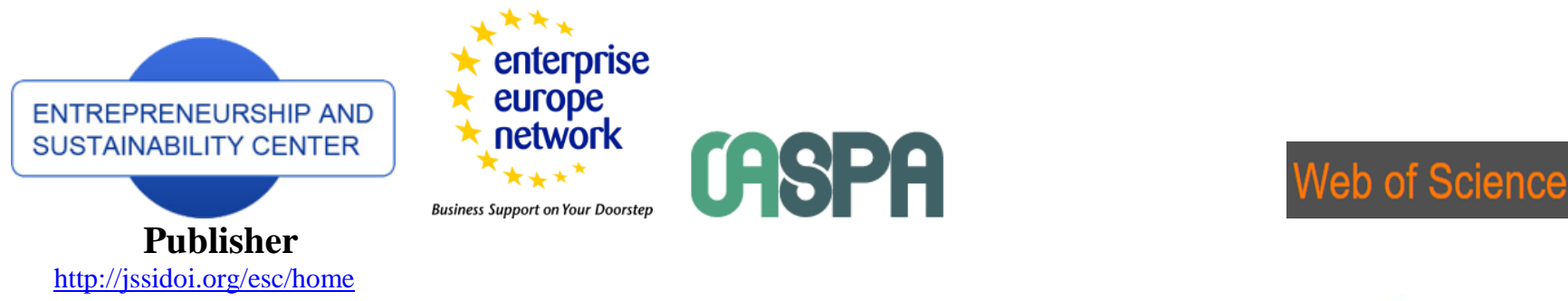

http://jssidoi.org/esc/home

\title{
CORPORATE GOVERNANCE AND THE PERFORMANCE OF NON-FINANCIAL FIRMS: THE CASE OF OMAN
}

\author{
Hana Bawazir ${ }^{1}$, Anis Khayati ${ }^{2}$, Fatema AbdulMajeed ${ }^{3}$ \\ ${ }^{1,2}$ University of Bahrain, College of Business Administration, Zallaq, Bahrain \\ ${ }^{3}$ Ministry of Interior, Manama, Bahrain \\ E-mails:1hbawazir@uob.edu.bh; ${ }^{2}$ aelkhayati@uob.edu.bh; ${ }^{3}$ fa.ghaibullah@interior.gov.bh
}

Received 11 March 2021; accepted 28 April 2021; published 30 June 2021

\begin{abstract}
Last two decades, corporate accounting scandals have represented a serious challenge to economic sustainability. To protect the shareholders right against abusive managerial conduct, the concepts of corporate governance structures and provisions have widely attracted the attention of practitioners and researchers. The main purpose of this paper is to examine the linkage between corporate governance and the performance of non-financial firms listed on Muscat Securities Market over the period 2007-2017. Additionally, whether financial leverage acts as a mediating factor is investigated. A panel fixed effect regression is conducted to test if there is a relationship between corporate governance, capital structure and firm performance. Overall results show that women on board, audit committee size, leverage and firm size are positively related to firm performance. The study presents a strong understanding to senior management to be focused more on corporate governance codes and regulations, as well as to both internal and external auditors to strictly monitor the application of corporate governance regulations.
\end{abstract}

Keywords: Corporate governance; financial leverage; capital structure; firm performance; Oman; Gulf Cooperation Council (GCC) Countries.

Reference to this paper should be made as follows: Bawazir, H., Khayati, A., AbdulMajeed, F. 2021. Corporate governance and the performance of non-financial firms: the case of Oman. Entrepreneurship and Sustainability Issues, 8(4), 595-609. http://doi.org/10.9770/jesi.2021.8.4(36)

JEL Classifications: G34, O14, L25, M21

\section{Introduction}

Corporate governance is the set of relationships and responsibilities between people involved in companies and external stakeholders establishing rules, policies and procedures appropriated for the management, administration and business control (Badele \& Fundeanu, 2014). In the early 2000s, due to corporate accounting scandals, many public and academic exhibited their interest in corporate governance provision to protect the shareholders right against the abusive managerial conduct (Madanoglu et al. 2018). The major collapse of Enron, WorldCom and HIH insurance and the collapse of the Maxwell publishing Group, BCCI and Poly Peck in the United Kingdom has raised the questions on board's ability while monitoring the management (Rashid, 2018). Thus, the global economic crisis of 2007 forced rigid public, political and regulatory scrutiny on the adoption of obligatory 


\section{ENTREPRENEURSHIP AND SUSTAINABILITY ISSUES}

ISSN 2345-0282 (online) http://jssidoi.org/jesi/

2021 Volume 8 Number 4 (June)

http://doi.org/10.9770/jesi.2021.8.4(36)

corporate governance practices of worldwide companies. Corporate governance also facilitates the company to maximize the value of the firm which can be observed through the performance of the firm (Gupta \& Sharma, 2014).

Meanwhile, the firm performance is seen as an indicator of achieving the company's objectives and that should be continuously improved and maintained to attract investors and to retain good affiliation with stakeholders (Badriyah et al. 2015). Firm performance might also affect the choice of capital structure (Margaritis \& Psillaki, 2010), and corporate governance can be used as a tool to reduce the conflicts between agents, which may have impact on a firm's capital structure (Detthamrong et al. 2017).

The theory of corporate governance also states that the impact of leverage on agency cost can also influence the firm performance (Berger \& Di Patti, 2006). The term capital structure was first used by Modigliani and Miller (1958) and it can be used "to transfer control from managers to security holders: either to creditors in bankruptcy, or to raiders in takeovers" (Maug, 1997, p.115).

There are few empirical researches that have studied the corporate governance and firm performance in Omani listed firms. To the best of our knowledge, taking financial leverage as a mediating factor between corporate governance and firm performance has not been previously investigated on Omani listed firms. Therefore, empirical evidence in this area is still lacking.

The following research questions are going to be framed as scientific hypotheses to be tested:

- Is there any positive impact of corporate governance on firm performance?

- Is there any positive impact of financial leverage on firm performance?

- Does Financial leverage mediate the influence of corporate governance on the performance of Omani listed non-financial firms?

This research is significant for the following two reasons. Firstly, very few studies have investigated whether corporate governance enriches firm's performance in the context of Omani listed firms. Abdallah \& Ismail (2017) and Pillai \& Al-Malkawi, (2018) studied the relationship between corporate governance and firm performance in GCC countries and used ROA, ROE to measure the performance of the firms. Though, these studies did not measure the overall firms' performance in terms of price-earning-ratio. Secondly, the act of financial leverage as a mediator between corporate governance and firm performance has not been addressed in the context of Omani firms. Using a panel data set for the period 2000-2010, Zeitun (2014) examined the corporate governance, capital structure and corporate performance in GCC countries. However, this study overlooked the impact of corporate governance variables such as independent directors, female directors, audit committee size, etc. Al-Matari et al. (2014) studied the effect of board of directors' characteristics and audit committee characteristics on firm performance in Oman for the limited period 2011-2012. However, this study also overlooked some variables such as female directorship. Accordingly, in the context of Omani firms, none of the empirical literature tested the role of financial leverage as a mediating variable between corporate governance and firm performance.

The main purpose of this study is to find whether corporate governance and capital structure enhance the performance of the non-financial firms in Oman. The paper is organized as follows: The introduction provides an overview of introduction to the research problem, research objectives, questions and significance of the research study. Section 2 describes the methodology, data and variables used in this study. Section 3 discusses the results and findings based on different models. Finally, section 4 concludes. 


\section{Empirical Analysis}

\subsection{Variables and Data Selection}

Table 1 shows the variables used in this study. The set of data consist of information about non-financial firms listed in Muscat Securities Market. Data for ROA, ROE, and financial leverage are gathered from the firms' balance sheets and income statements. Corporate governance variables are gathered from the reports of the listed firms in Muscat Securities Market official website, and the data for share price are taken from the Thomson Reuters DataStream.

Table 1. Variables

\begin{tabular}{|c|c|c|}
\hline Type & Variables & Description of Variables \\
\hline \multirow{3}{*}{ Dependent Variables } & Return on Assets (ROA) & ROA= Net Income/Total Assets \\
\hline & Return on Equity (ROE) & ROE $=$ Net Income/Total equity \\
\hline & Price- Earning Ratio (P/E) & $\mathrm{P} / \mathrm{E}=$ Share Price/Earnings per Share \\
\hline \multirow{7}{*}{ Independent Variables } & Board Size (BS) & The total Number of directors on the firm's board \\
\hline & Board Meetings (BM) & number of annual board meetings \\
\hline & Board Independence (BIND) & $\begin{array}{l}\text { Board Independence is a dummy variable which take a } \\
\text { value of one for firms employing independent directors } \\
\text { and zero otherwise }\end{array}$ \\
\hline & Female Directorship (BWOM) & BWOMEN= Female directors/total number of directors \\
\hline & Audit Committee Size (AS) & the number of audit committee on the board \\
\hline & Audit reputation (BIG4) & $\begin{array}{c}\text { A dummy variable, which takes the value of one for the } \\
\text { firms where firm's auditor is one of the big four } \\
\text { auditing firms and zero otherwise. KPMG, Deloitte, } \\
\text { PricewaterhouseCoopers and EY are big four auditing } \\
\text { firms }\end{array}$ \\
\hline & Leverage (LEV) & $\mathrm{LEV}=$ Total liabilities/total assets \\
\hline \multirow{3}{*}{ Control Variables } & Tangibility Ratio (TR) & $\mathrm{TR}=$ Fixed assets/total assets \\
\hline & Current Ratio (CR) & $\mathrm{CR}=$ Current assets/current liabilities \\
\hline & Firm Size (FS) & $\begin{array}{c}\text { Firm size is measured as the natural logarithm of Total } \\
\text { Assets }\end{array}$ \\
\hline
\end{tabular}

Source: authors

The sample of this research study covers 53 non-financial firms over the period 2007 - 2017. There were 80 nonfinancial firms listed as of $30^{\text {th }}$ December 2017. However, 27 companies have been excluded due to nonavailability of data during the study period. Financial firms are excluded as they differ in their legal requirements, structure, methods and accounting practices.

The data was collected manually. Therefore, to minimize the possible data recording errors and outliers, all variables were winsorized. The Winsorization procedure sets a limit from the rest of the sample on how far away an extreme observation is to be allowed (Cowan \& Sergeant, 2001). 
The sample data is analyzed using the EViews 9 software. Both random and fixed effect regressions are conducted to observe if there is a relationship between corporate governance, capital structure and firm performance. Hausman test is performed to decide whether random effect or fixed effect regressions are suitable for panel data (Wooldridge, 2012). Before running the regressions, multicollinearity is analyzed using the variance inflation factor (VIF) and residual normality tests. If the residual normality test is less than 0.05 , the natural logarithm is applied. Accordingly, natural logarithm is taken for the variable P/E ratio.

\subsection{Research Hypotheses and Models}

Figure 1 shows the conceptual framework of this study. The conceptual framework provides a basis to recognize the impact of corporate governance and capital structure variables on firm performance and allows the development of hypotheses (Jabareen, 2009). This conceptual framework involves various dependent, independent and control variables.

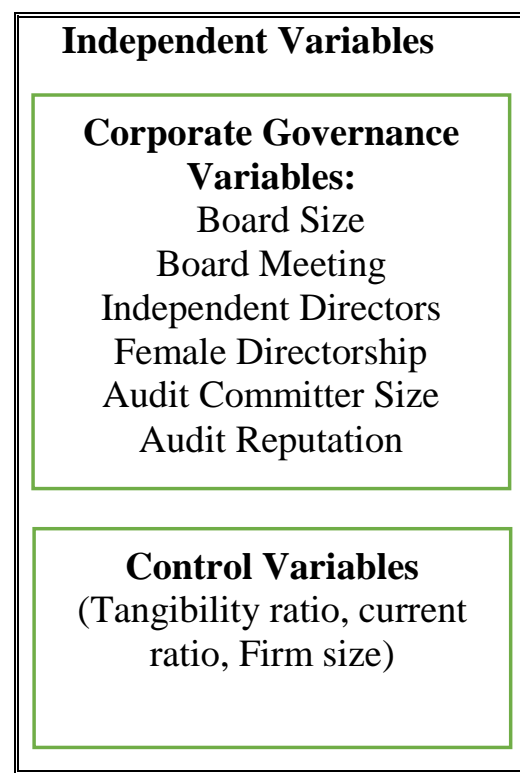

$\mathrm{H} 3$

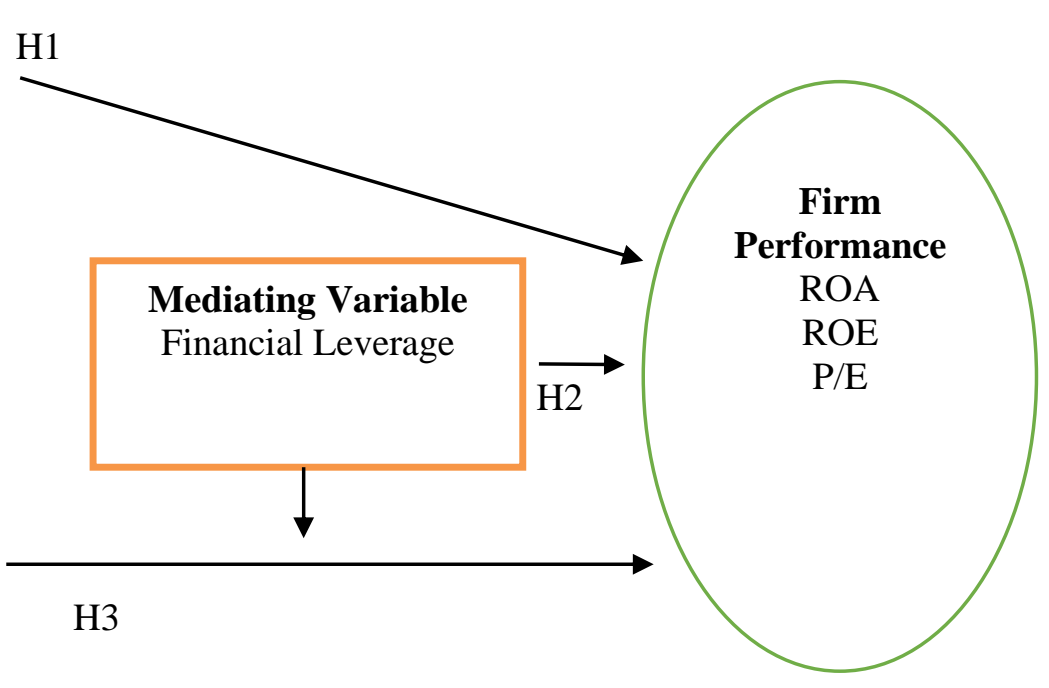

Figure 1. The conceptual framework of this study

The following hypotheses are developed based on previous literature:

H1: The impacts of corporate governance on firm performance Hypothesis 1.1: Board size is positively associated with firm performance. Hypothesis 1.2: Number of Board meetings is positively associated with the firm performance Hypothesis 1.3: Board Independence is positively associated with the firm performance. Hypothesis 1.4: Female directorship is positively associated with firm performance. Hypothesis 1.5: Audit committee size is positively associated with firm performance. Hypothesis 1.6: Audited reputation is positively associated with firm performance

H2: The impacts of financial leverage on firm performance Hypothesis 2: Financial leverage is positively associated with firm performance. 


\section{ENTREPRENEURSHIP AND SUSTAINABILITY ISSUES}

ISSN 2345-0282 (online) http://jssidoi.org/jesi/

2021 Volume 8 Number 4 (June)

http://doi.org/10.9770/jesi.2021.8.4(36)

H3: The mediating impacts of financial leverage on the association between corporate governance and firm performance.

Hypothesis 3.1: Financial Leverage mediates the effect of Board Size on firm performance.

Hypothesis 3.2: Financial Leverage mediates the effect of Board meeting on firm performance.

Hypothesis 3.3: Financial Leverage mediates the effect Board Independence on firm performance.

Hypothesis 3.4: Financial Leverage mediates the effect Female Directorship on firm performance.

Hypothesis 3.5: Financial Leverage mediates the effect Audit committee size on firm performance.

Hypothesis 3.6: Financial Leverage mediates the effect Audit Reputation on firm performance.

In this study, three research models are presented. The first model tests the impact of corporate governance on firm performance. The second model investigates the effect of financial leverage on firm performance and the

third model tests the impact of corporate governance and financial leverage on firm performance. Therefore, the firm performance is a dependent variable in all three models. In addition to independent variables, control variables that are important in determining the performance of the firm are also considered. The details of all three models are presented as follows.

Model 1: The impact of corporate governance on firm performance

$$
\boldsymbol{Y}_{i t}=\beta_{0}+\beta X_{i t}+\gamma Z_{i t}+\varepsilon_{i t}(\mathbf{1})
$$

Where $\mathrm{Y}_{\mathrm{it}}$ is the dependent variables (ROA, ROE and $\mathrm{P} / \mathrm{E}$ ratio) for firm $i$ at $t$ time. $\mathrm{X}$ is a corporate governance variable for firm $i$ at time $t, \mathrm{Z}$ is control variables and $\varepsilon$ is the error term.

$$
\begin{aligned}
R O A_{i t}=\beta_{0}+ & \beta_{1}(B S I Z E)_{i t}+\beta_{2}(B M)_{i t}+\beta_{3}(B I N D)_{i t}+\beta_{4}(B W O M E N)_{i t}+\beta_{5}(A S I Z E)_{i t} \\
& +\beta_{6}(B I G 4)_{i t}+\gamma_{1}(T R)_{i t}+\gamma_{2}(C R)_{i t}+\gamma_{3}(\text { FIIZE) })_{i t}+\varepsilon_{i t} \\
R O E_{i t}=\beta_{0}+\beta_{1}(B S I Z E)_{i t}+\beta_{2}(B M)_{i t}+\beta_{3}(B I N D)_{i t}+\beta_{4}(B W O M E N)_{i t}+\beta_{5}(A S I Z E)_{i t} & +\beta_{6}(B I G 4)_{i t}+\gamma_{1}(T R)_{i t}+\gamma_{2}(C R)_{i t}+\gamma_{3}(\text { FIIZE) })_{i t}+\varepsilon_{i t} \\
P / E_{i t}=\beta_{0}+\beta_{1}(B S I Z E)_{i t}+\beta_{2}(B M)_{i t}+\beta_{3}(B I N D)_{i t}+\beta_{4}(B W O M E N)_{i t}+\beta_{5}(A S I Z E)_{i t} & +\beta_{6}(B I G 4)_{i t}+\gamma_{1}(T R)_{i t}+\gamma_{2}(C R)_{i t}+\gamma_{3}(\text { FIIZE) })_{i t}+\varepsilon_{i t}
\end{aligned}
$$

Model 2: The impact of the financial leverage on the firm performance

$$
Y_{i t}=\beta_{0}+\beta X_{i t}+\gamma Z_{i t}+\varepsilon_{i t}
$$

Where $\mathrm{Y}_{\mathrm{it}}$ is the dependent variables (ROA, ROE and $\mathrm{P} / \mathrm{E}$ ratio) for firm $i$ at $t$ time. $\mathrm{X}$ is a leverage for firm $i$ at time $t, \mathrm{Z}$ is control variables and $\varepsilon$ is the error term.

$$
\begin{aligned}
& R O A_{i t}=\beta_{0}+\beta_{1}(L E V)_{i t}+\gamma_{1}(T R)_{i t}+\gamma_{2}(C R)_{i t}+\gamma_{3}(\text { FSIZE })_{i t}+\varepsilon_{i t} \\
& R O E_{i t}=\beta_{0}+\beta_{1}(L E V)_{i t}+\gamma_{1}(T R)_{i t}+\gamma_{2}(C R)_{i t}+\gamma_{3}(\text { FSIZE })_{i t}+\varepsilon_{i t} \\
& P / E_{i t}=\beta_{0}+\beta_{1}(L E V)_{i t}+\gamma_{1}(T R)_{i t}+\gamma_{2}(C R)_{i t}+\gamma_{3}(\text { FSIZE })_{i t}+\varepsilon_{i t}
\end{aligned}
$$

Where ROA - return on assets; ROE- return on equity; P/E - Price-Earning-Ratio; Lev - financial leverage; TRtangibility ratio; CR- current ratio; FSize- firm size; $\varepsilon$ ij probable error. 
Model 3: The impact of corporate governance and financial leverage on firm performance

$$
Y_{i t}=\beta_{0}+\beta C G_{i t}+\delta(L E V)_{i t}+\gamma Z_{i t}+\varepsilon_{i t}
$$

Where $\mathrm{Y}_{\mathrm{it}}$ is the dependent variables (ROE and $\mathrm{P} / \mathrm{E}$ ) for firm $i$ at $t$ time. CG is corporate governance variables for firm $i$ at time and LEV is a leverage for firm $i$ at time $t$. Z is control variables and $\varepsilon$ is the error term.

$$
\begin{aligned}
R O E_{i t}=\beta_{0}+ & \beta_{1}(B S I Z E)_{i t}+\beta_{2}(B M)_{i t}+\beta_{3}(B I N D)_{i t}+\beta_{4}(B W O M E N)_{i t}+\beta_{5}(A S I Z E)_{i t} \\
& +\beta_{6}(B I G 4)_{i t}+\delta_{1}(L E V)_{i t}+\gamma_{1}(T R)_{i t}+\gamma_{2}(C R)_{i t}+\gamma_{3}(F S I Z E)_{i t}+\varepsilon_{i t} \\
P / E_{i t}=\beta_{0}+ & \beta_{1}(B S I Z E)_{i t}+\beta_{2}(B M)_{i t}+\beta_{3}(B I N D)_{i t}+\beta_{4}(B W O M E N)_{i t}+\beta_{5}(A S I Z E)_{i t} \\
& +\beta_{6}(B I G 4)_{i t}+\delta_{1}(L E V)_{i t}+\gamma_{1}(T R)_{i t}+\gamma_{2}(C R)_{i t}+\gamma_{3}(\text { FSIZE })_{i t}+\varepsilon_{i t}
\end{aligned}
$$

\section{Results and Discussion}

Table 2 provides the descriptive results of all variables.

Table 2. Descriptive Statistics

\begin{tabular}{|c|c|c|c|c|}
\hline Variable & Mean & Std. Dev. & Maximum & Minimum \\
\hline ROA & 0.07 & 0.07 & 0.25 & -0.11 \\
\hline ROE & 0.12 & 0.13 & 0.42 & -0.16 \\
\hline P/E & 1.54 & 0.0009 & 1.55 & 1.5 \\
\hline BS & 7.31 & 1.47 & 11 & 4 \\
\hline BM & 5.91 & 1.95 & 15 & 4 \\
\hline BIND & 1.00 & 0.06 & 1 & 0 \\
\hline BWOM & 0.03 & 0.07 & 0.33 & 0 \\
\hline AS & 3.46 & 0.68 & 6 & 2 \\
\hline BIG4 & 0.69 & 0.46 & 1 & 0 \\
\hline LEV & 0.39 & 0.23 & 1.05 & 0.005 \\
\hline TR & 0.47 & 0.27 & 0.99 & 0 \\
\hline CR & 2.13 & 1.39 & 5.07 & 0.05 \\
\hline FS & 16.88 & 1.34 & 20.50 & 14.53 \\
\hline
\end{tabular}

Source: Authors' calculation

Table 2 indicates that the mean value of ROA is 0.07 or $7 \%$. The mean ROE is $12 \%$, while the mean value of P/E is 1.54. The mean value of Board Size is 7 with the largest BS having 11 members. Further, the mean value of board meeting is 6 with the largest board meetings held is 15 . The results reveal that mean value of board independent is 1 , while the female directorship is $3 \%$. The results further revealed that mean value of audit committee size is 3 and $69 \%$ of the firms engaged auditors from the big4. The mean value results for leverage is 0.39. Finally, for the control variables, the results for mean value for tangibility ratio and current ratio are respectively 0.47 and 2.13 . On average, the firm size is 17 . 
Table 3. Pairwise Correlation Matrix

\begin{tabular}{|c|c|c|c|c|c|c|c|c|c|c|c|c|c|}
\hline \multicolumn{14}{|c|}{ Pearson Correlations Matrix } \\
\hline & ROA & ROE & $\mathrm{PE}$ & $\mathrm{BS}$ & BM & BIND & BWOM & AS & BIG4 & LEV & TR & $\mathrm{CR}$ & $\mathrm{FS}$ \\
\hline ROA & 1 & & & & & & & & & & & & \\
\hline ROE & $.839^{* *}$ & 1 & & & & & & & & & & & \\
\hline $\mathrm{PE}$ & $-1.000^{* *}$ & $-.839^{* *}$ & 1 & & & & & & & & & & \\
\hline BS & .009 & .044 & -.010 & 1 & & & & & & & & & \\
\hline BM & .029 & .008 & -.029 & .020 & 1 & & & & & & & & \\
\hline BIND & .034 & .031 & -.034 & .012 & .027 & 1 & & & & & & & \\
\hline BWOM & .062 & $.107^{*}$ & -.062 & $.135^{* *}$ & -.074 & $-.100^{*}$ & 1 & & & & & & \\
\hline AS & .028 & .019 & -.028 & $.472^{* *}$ & $.144^{* *}$ & -.046 & $-.083^{*}$ & 1 & & & & & \\
\hline BIG4 & .078 & $.159^{* *}$ & -.077 & $.191^{* *}$ & $.149^{* *}$ & -.039 & $.185^{* *}$ & .069 & 1 & & & & \\
\hline LEV & $-.315^{* *}$ & .020 & $.315^{* *}$ & -.001 & -.037 & -.020 & $.167^{* *}$ & -.017 & $.118^{* *}$ & 1 & & & \\
\hline TR & $-.218^{* *}$ & $-.180^{* *}$ & $.218^{* *}$ & .077 & $-.087^{*}$ & .056 & .044 & $-.117^{* *}$ & .074 & .008 & 1 & & \\
\hline CR & $.344^{* *}$ & $.097^{*}$ & $-.344^{* *}$ & $-.148^{* *}$ & -.022 & .048 & -.065 & -.020 & $-.129^{* *}$ & $-.597^{* *}$ & $-.315^{* *}$ & 1 & \\
\hline FS & $.154^{* *}$ & $.231^{* *}$ & $-.154^{* *}$ & $.301^{* *}$ & $.261^{* *}$ & .026 & $.110^{* *}$ & $.146^{* *}$ & $.405^{* *}$ & $.144^{* *}$ & -.057 & $-.170^{* *}$ & 1 \\
\hline
\end{tabular}

Table 3 reports correlations between variables used in the study. The results show a high correlation between ROA and $\operatorname{ROE}(\mathrm{r}=0.839)$. This is expected as both variables are indicators of profitability. P/E is also significantly correlated with ROA and ROE. Thus, the variables can be used interchangeably as a proxy for the firm performance. It is evident from the correlation analysis that there is not a very significant correlation between independent and dependent variables. In effect, board size, board independence and board meeting are insignificantly correlated to all dependent variables.

However, board women and ROE are significantly correlated which suggest that more women on board would result in high shareholders returns. There is also a significant correlation between board women, financial leverage and firm size. This would indicate that firms with women on board are highly leveraged.

It is evident that big4 is significantly correlated with ROE. There is also a significant correlation between big4 and financial leverage. Employing auditors from reputable firms would increase the trustworthiness of the firms to the public and financing agents. In addition, financial leverage is also significantly correlated with ROA and P/E.

Finally, control variables (CR, TR and FS) do not reveal high correlation with corporate governance variables. The maximum correlation (0.4) is shown between big4 and firm size.

Before the regression analysis is undertaken, the data was tested. The tests include multicollinearity and residual normal distributions.

Multicollinearity is a statistical problem that arises if all or some of the independent variables are highly correlates with each other (Koop, 2006). Multicollinearity is tested using the variance inflation factor (VIF) method for all variables. 
Table 4. Various Inflation Factor

\begin{tabular}{|l|l|}
\hline Variable & VIF \\
\hline Board Size & 1.53 \\
\hline Board Meeting & 1.13 \\
\hline Board independence & 1.03 \\
\hline Board Women & 1.13 \\
\hline Audit Committee Size & 1.40 \\
\hline BIG4 & 1.26 \\
\hline Leverage & 1.76 \\
\hline Tangibility Ratio & 1.25 \\
\hline Current Ratio & 1.94 \\
\hline Firm Size & 1.40 \\
\hline Mean VIF & 1.38 \\
\hline
\end{tabular}

Table 4 presents the results of multicollinearity using VIF tests. The results conclude that there is not a serious issue of multicollinearity. In order to detect whether residuals are normally distributed, the Jarque-Bera test is conducted (Table 5).

Table 5. Jarque-Bera test results

\begin{tabular}{|c|c|c|c|}
\hline & Obs. & P-Value & Result \\
\hline \multicolumn{4}{|c|}{$\mathrm{H}_{0}$ : Residual is normally distributed } \\
\hline \multicolumn{4}{|c|}{$\mathrm{H}_{1}$ : Residual is not normally distributed } \\
\hline Standardized Residual (ROA) & 583 & 0.129 & \multirow{3}{*}{$\begin{array}{l}\text { Cannot reject that } \\
\text { residuals are } \\
\text { normally distributed }\end{array}$} \\
\hline Standardized Residual (ROE) & 583 & 0.154 & \\
\hline Standardized Residual (PE) & 583 & 0.147 & \\
\hline
\end{tabular}

Then, in order to choose between a random effects model and a fixed effects model, a Hausman test was used (Table 6).

Table 6. Hausman Test Results

\begin{tabular}{|l|l|}
\hline $\mathrm{H}_{0}:$ Random effect Panel Data are preferred & \\
\hline $\mathrm{H}_{1}:$ Fixed effect Panel Data are preferred & \\
\hline p-value & 0.0000 \\
\hline Note: $*$ Significant at $5 \%$. &
\end{tabular}

The results in Table 6 show that the fixed effect regression model is suitable for the data. 


\section{ENTREPRENEURSHIP AND SUSTAINABILITY ISSUES}

ISSN 2345-0282 (online) http://jssidoi.org/jesi/

2021 Volume 8 Number 4 (June)

http://doi.org/10.9770/jesi.2021.8.4(36)

Table 7. The impact of corporate governance on firm performance

\begin{tabular}{|c|c|c|c|c|c|c|}
\hline Variable & $\begin{array}{c}\text { ROA } \\
\text { Coefficient }\end{array}$ & Std. Error & $\begin{array}{c}\text { ROE } \\
\text { Coefficient }\end{array}$ & Std. Error & $\begin{array}{c}\text { PE } \\
\text { Coefficient }\end{array}$ & Std. Error \\
\hline C & 0.63049 & 0.12668 & 1.098078 & 0.236803 & 1.53544 & 0.0015770 \\
\hline & $(0.0000)^{* * *}$ & & $(0.0000)^{* * *}$ & & $(0.0000)^{* * *}$ & \\
\hline BS & -0.00456 & 0.00391 & -0.003933 & 0.007309 & 0.00005730 & 0.0000487 \\
\hline & $(0.2446)$ & & $(0.5907)$ & & $(0.2400)$ & \\
\hline BM & -0.00233 & 0.00144 & -0.005317 & 0.002695 & 0.00002890 & 0.0000179 \\
\hline & $(0.1070)$ & & $(0.0491)^{* *}$ & & $(0.1074)$ & \\
\hline BIND & 0.03644 & 0.03717 & 0.052571 & 0.069482 & -0.000455 & 0.0004630 \\
\hline & $(0.3274)$ & & $(0.4496)$ & & $(0.3255)$ & \\
\hline BWOM & 0.02810 & 0.06112 & 0.238172 & 0.114245 & -0.000355 & 0.0007610 \\
\hline & $(0.6459)$ & & $(0.0376)^{* *}$ & & $(0.6407)$ & \\
\hline AS & -0.01205 & 0.00583 & -0.015865 & 0.010889 & 0.000151 & 0.0000725 \\
\hline BIG4 & $(0.0392)^{* *}$ & & $(0.1457)$ & & $(0.0377)^{* *}$ & \\
\hline & 0.01412 & 0.00681 & 0.00851 & 0.012736 & -0.000176 & 0.0000848 \\
\hline TR & $(0.0387)^{* *}$ & & $(0.5043)$ & & $(0.0381)^{* *}$ & \\
\hline & 0.02818 & 0.02209 & 0.051629 & 0.041289 & -0.000353 & 0.0002750 \\
\hline CR & $(0.2026)$ & & $(0.2117)$ & & $(0.1995)$ & \\
\hline & 0.01294 & 0.00267 & 0.00842 & 0.004983 & -0.000161 & 0.0000332 \\
\hline FS & $(0.0000)^{* * *}$ & & $(0.0917)^{*}$ & & $(0.0000)^{* * *}$ & \\
\hline & $(0.03300$ & 0.0069 & -0.05735 & 0.012815 & 0.000412 & 0.0000853 \\
\hline F-statistic & 15.42123 & & $(0.0000)^{* * * *}$ & & $(0.0000)^{* * * *}$ & \\
\hline $\begin{array}{l}\text { Prob(F- } \\
\text { statistic) }\end{array}$ & $(0.0000)^{* * *}$ & & 11.64325 & & 15.44208 & \\
\hline R-squared & 0.643564 & & $(0.0000)^{* * *}$ & & $(0.0000)^{* * * *}$ & \\
\hline $\begin{array}{l}\text { Adjusted } \\
\text { squared }\end{array}$ & 0.601832 & & 0.57685 & & 0.643874 & \\
\hline
\end{tabular}

Note: $* * *$ Indicate significant at $1 \%, * *$ at $5 \%$ and $*$ at $10 \%$

Table 7 presents the results of fixed effect panel regression where the dependent variables are ROA (return on assets), ROE (return on equity) and P/E (price earnings ratio). Results indicate the significant and positive impact of audit committee size (AS) on price earnings ratio, which is consistent with hypothesis 1.5. On another hand, the results show that the coefficient of AS is -0.012 .5 and it statistically significant at the $5 \%$ level with ROA. The AS negative relationship with ROA suggest that an increase in the audit size will result in decrease in return on assets. This result is consistent with the study of Detthamrong et al. (2017), who also reported negative relationship between ROA and AS. Table 7 also shows negative but insignificant impact of AS on ROE. This result is consistent with Zhou et al., (2018) who reported insignificant association between AS and firm performance. The negative impact of AS on ROA and its insignificant impact on ROE suggest that Omani firms form AS only to act in accordance with the regulatory requirements rather than for other purposes.

Regarding audit reputation (Big4), the panel fixed regression results show significant and positive impact of Big4 on ROA. This result is consistent with the studies of Conheady et al. (2015), Aktan, et al., (2018) and Sial et al. (2018), who argue that audited financial reports from Big4 can help to reduce the possibility of frauds in the firms, which in turn develop investors' confidence.

The board meetings variable (BM) shows significant and negative impact on ROE. Aktan et.al. (2018) also reported negative relationship between board meeting and performance of firms listed on Bahrain Bourse for the 


\section{ENTREPRENEURSHIP AND SUSTAINABILITY ISSUES}

ISSN 2345-0282 (online) http://jssidoi.org/jesi/

2021 Volume 8 Number 4 (June)

http://doi.org/10.9770/jesi.2021.8.4(36)

period 2011- 2016. The authors stated that instead of being constructive, board meetings can be destructive, since management is placed under greater autonomy and less inspection.

The variable of female directors on board shows positive and significant association with ROE. The results are consistent with previous studies that also reported positive association between women on board and firm performance. This variable can be an essential driver of board effectiveness and may influence firm performance (Liu et al., 2014; Garcia-Torea, et al., 2016; and Ahmadi et al. 2018).

The results indicate that other corporate governance variables such as board size and board independence are not associated with firm performance. A number of previous studies also showed insignificant association of board size and board independent on firm performance and suggested that corporate governance variables do not necessarily enhance performance (Zabri et al., 2016; Panditharathna \& Kawshala, 2017; Eluyela et al., 2018; Y1lmaz, 2018).

Finally, the control variable tangibility ratio (TR) is also not a significant variable in the determination of firm performance (ROA, ROE and PE), while the control variables current ratio (CR) and firm size (FS) are significant factors in determining the performance of the firm.

Results in Table 8 show that leverage is significant in explaining variations in firm profitability. The coefficients of leverage have a positive value of respectively 0.098815 and 0.000876 . The estimated value of ROE and PE is predicated to increase when the leverage increases. The positive relationship between leverage and performance may be due to the fact that creditors monitor firms in a better way and thus lessen the investment problems. The results are consistent with a number of studies (Fosu, 2013; Handoo \& Sharma, 2014; Pillai \& Al-Malkawi, 2018; Ramli et al., 2019).

Table 8. The impacts of financial leverage on firm performance

\begin{tabular}{|c|c|c|c|c|c|c|}
\hline Variable & $\begin{array}{c}\text { ROA } \\
\text { Coefficient }\end{array}$ & Std. Error & $\begin{array}{c}\text { ROE } \\
\text { Coefficient }\end{array}$ & Std. Error & PE Coefficient & Std. Error \\
\hline \multirow[t]{2}{*}{$\mathbf{C}$} & 0.611116 & 0.114622 & 0.99835 & 0.21503 & 1.535687 & 0.001427 \\
\hline & $(0.0000) * * *$ & & $(0.0000) * * *$ & & $(0.0000)^{* * *}$ & \\
\hline \multirow[t]{2}{*}{ LEV } & -0.070693 & 0.020576 & 0.098815 & 0.0386 & 0.000876 & 0.000256 \\
\hline & $(0.0006) * * *$ & & $(0.0107)^{* *}$ & & $(0.0007)^{* * *}$ & \\
\hline \multirow[t]{2}{*}{ TR } & 0.024602 & 0.021706 & 0.072438 & 0.04072 & -0.000309 & 0.00027 \\
\hline & $(0.2576)$ & & $(0.0758)^{*}$ & & $(0.2532)$ & \\
\hline \multirow[t]{2}{*}{$\mathbf{C R}$} & 0.007849 & 0.002996 & 0.016156 & 0.00562 & $-9.80 \mathrm{E}-05$ & 0.0000373 \\
\hline & $(0.0091)^{* *}$ & & $(0.0042)^{* *}$ & & $(0.0089)^{* *}$ & \\
\hline \multirow[t]{2}{*}{ FS } & -0.03195 & 0.006601 & -0.058254 & 0.01238 & 0.000399 & 0.00008220 \\
\hline & $(0.0000)^{* * *}$ & & $(0.0000) * * *$ & & $(0.0000) * * *$ & \\
\hline F-statistic & 16.8502 & & 12.5555 & & 16.8615 & \\
\hline $\begin{array}{l}\text { Prob(F- } \\
\text { statistic) }\end{array}$ & $(0.0000)^{* * *}$ & & $(0.0000)^{* * *}$ & & $(0.0000)^{* * * *}$ & \\
\hline R-squared & 0.6421 & & 0.5720 & & 0.6422 & \\
\hline $\begin{array}{l}\text { Adjusted R- } \\
\text { squared }\end{array}$ & 0.6040 & & 0.5265 & & 0.6041 & \\
\hline
\end{tabular}

Note: $* * *$ Indicate significant at $1 \%, * *$ at $5 \%$ and $*$ at $10 \%$

On other hand, the negative coefficient value of leverage -0.07069 indicates negative relationship with ROA. Thus, the estimated value of ROA is predicted to decrease when the leverage increases. Previous studies also reported negative relationship between leverage and firm performance (Salim \& Yadav, 2012; Vătavu, 2015; Singh, 2016). The negative association between ROA and leverage is also recorded by Al Ani \& Al Amri, (2015) in a study conducted on Omani industrial firms listed on Muscat securities Market over the period 2008-2012. 
To test whether financial leverage mediates the impact of financial leverage on firm performance, the results of panel regression analysis are presented in Table 9 . Since ROA and ROE are highly correlated $(\mathrm{r}=.839)$, they can be used interchangeably (Detthamrong et al., 2017). Thus, ROE is used as a proxy for firm performance. The models of ROE and PE fit the data well as all regression coefficients F-test are jointly equal to zero is rejected.

Table 9. The mediating impacts of financial leverage on the association between corporate governance and firm performance.

\begin{tabular}{|c|c|c|c|c|}
\hline Variable & ROE Coefficient & Std. Error & PE Coefficient & Std. Error \\
\hline \multirow[t]{2}{*}{$\mathbf{C}$} & 1.060161 & 0.236051 & 1.535111 & 0.001565 \\
\hline & $(0.0000) * * *$ & & $(0.0000)^{* * *}$ & \\
\hline \multirow[t]{2}{*}{ BS } & -0.003634 & 0.007272 & $5.99 \mathrm{E}-05$ & 0.00004820 \\
\hline & $(0.6175)$ & & $(0.2150)$ & \\
\hline \multirow[t]{2}{*}{ BM } & -0.006002 & 0.002695 & 0.00002300 & 0.00001790 \\
\hline & $(0.0263)^{* *}$ & & $(0.1986)$ & \\
\hline \multirow[t]{2}{*}{ BIND } & 0.049958 & 0.06913 & -0.000478 & 0.000458 \\
\hline & $(0.4702)$ & & $(0.2975)$ & \\
\hline \multirow[t]{2}{*}{ BWOM } & 0.199419 & 0.114676 & -0.000691 & 0.00076 \\
\hline & $(0.0826)^{*}$ & & $(0.3638)$ & \\
\hline \multirow[t]{2}{*}{ AS } & -0.015374 & 0.010835 & 0.000155 & 0.00007180 \\
\hline & $(0.1565)$ & & $(0.0310)^{* * *}$ & \\
\hline \multirow[t]{2}{*}{ BIG4 } & 0.011055 & 0.012709 & -0.000154 & 0.00008430 \\
\hline & $(0.3848)$ & & $(0.0678)^{*}$ & \\
\hline \multirow[t]{2}{*}{ LEV } & 0.098969 & 0.039012 & 0.000858 & 0.000259 \\
\hline & $(0.0115)^{* *}$ & & $(0.0010)^{* * *}$ & \\
\hline \multirow[t]{2}{*}{ TR } & 0.063121 & 0.041324 & -0.000254 & 0.000274 \\
\hline & $(0.1273)$ & & $(0.3552)$ & \\
\hline \multirow[t]{2}{*}{ CR } & 0.01555 & 0.005698 & $-9.94 \mathrm{E}-05$ & 0.0000378 \\
\hline & $(0.0066)^{* *}$ & & $(0.0088)^{* *}$ & \\
\hline FS & -0.058493 & 0.012756 & 0.000402 & 0.0000846 \\
\hline F-statistic & 11.67878 & & 15.6621 & \\
\hline $\operatorname{Prob}($ F-statistic) & $(0.0000) * * *$ & & $(0.0000)^{* * *}$ & \\
\hline R-squared & 0.582022 & & 0.65125 & \\
\hline Adjusted R-squared & 0.532186 & & 0.60967 & \\
\hline
\end{tabular}

Table 9 shows that there is a significant impact of BM, BWOM, AS and BIG4 on firm performance. On the other hand, BS and BIND are insignificant in determining variations in firm performance. The same results are reported in table 7, which indicates that financial leverage does not mediate the impact of corporate governance on the performance of firms.

Therefore, the results reject hypothesis 3 and indicate that in the context of Omani firms, the impact of corporate governance on firm performance is not mediated by financial leverage.

\section{Conclusion}

Many research studies were conducted on corporate governance and its impact on firm performance. Previous studies conducted on different areas, countries or regions revealed different results. Some studies indicated the significant positive association between corporate governance and firm performance, while others showed insignificant or negative association. 


\section{ENTREPRENEURSHIP AND SUSTAINABILITY ISSUES}

ISSN 2345-0282 (online) http://jssidoi.org/jesi/

2021 Volume 8 Number 4 (June)

http://doi.org/10.9770/jesi.2021.8.4(36)

The main objective of this research is to explain the relationship between corporate governance, capital structure and firm performance on the listed non-financial firms in Oman. The findings show that female directorship, audit committee size, leverage and firm size variables are positively related to firm performance (ROE and PE). On the other hand, audit committee size and leverage are negatively related to ROA. Whereas audit reputation is significantly and positively related to ROA, tangibility ratio does not have a significant impact on ROA, ROE and $\mathrm{PE}$ of firms in Oman. Finally, the findings indicate that financial leverage does not mediate the effect of corporate governance on Omani firms' performance. Some of these results may seem divergent to corporate governance concepts and the efforts of the capital market authority.

\section{References}

Abdallah, A. A. N., \& Ismail, A. K. (2017). Corporate governance practices, ownership structure, and corporate performance in the GCC countries. Journal of International Financial Markets, Institutions and Money, 46, 98-115.

DOI: https://doi.org/10.1016/j.intfin.2016.08.004

Al Ani, M., \& Al Amri, M. (2015). The determinants of capital structure: an empirical study of Omani listed industrial companies. Business: Theory and Practice, 16 (2), 159-167.

DOI: https://doi.org/10.3846/btp.2015.471

Ahmadi, A., Nakaa, N., \& Bouri, A. (2018). Chief Executive Officer attributes, board structures, gender diversity and firm performance among French CAC 40 listed firms. Research in International Business and Finance, 44, 218-226.

DOI: https://doi.org/10.1016/j.ribaf.2017.07.083

Al-Matari, E. M., Al-Swidi, A. K., \& Faudziah, H. B. F. (2014). The effect of the relationship between board of directors characteristics on firm performance in Oman: empirical study. Middle-East Journal of Scientific Research, 21(3), 556-574.

DOI: https://doi.org/10.5829/idosi.mejsr.2014.21.03.21410

Aktan, B., Turen, S., Tvaronavičienè, M., Celik, S., \& Alsadeh, H. A. (2018). Corporate governance and performance of the financial firms in Bahrain. Polish Journal of Management Studies, 17(1), 39-58.

DOI: https://doi.org/10.17512/pjms.2018.17.1.04

Badele, C. S., \& Fundeanu, D. (2014). Policy's Beneficiaries of Corporate Governance and Diversification Strategy. Procedia-Social and Behavioral Sciences, 124, 468-477.

DOI: https://doi.org/10.1016/j.sbspro.2014.02.509

Badriyah, N., Sari, R. N., \& Basri, Y. M. (2015). The effect of corporate governance and firm characteristics on firm performance and risk management as an intervening variable. Procedia Economics and Finance, 31, 868-875.

DOI: https://doi.org/10.1016/S2212-5671(15)01184-3

Berger, A. N., \& Di Patti, E. B. (2006). Capital structure and firm performance: A new approach to testing agency theory and an application to the banking industry. Journal of Banking \& Finance, 30(4), 1065-1102.

DOI: https://doi.org/10.1016/j.jbankfin.2005.05.015

Conheady, B., McIlkenny, P., Opong, K. K., \& Pignatel, I. (2015). Board effectiveness and firm performance of Canadian listed firms. The British Accounting Review, 47(3), 290-303.

DOI: https://doi.org/10.1016/j.bar.2014.02.002

Cowan, R. A., \& Sergeant, M. A. A. (2001). Interacting biases, non-normal return distributions and the performance of tests for longhorizon even studies. Journal of Banking \& Finance, 25(4), 741-765.

DOI: https://doi.org/10.1016/S0378-4266(00)00094-7

Detthamrong, U., Chancharat, N., \& Vithessonthi, C. (2017). Corporate governance, capital structure and firm performance: evidence from Thailand. Research in International Business and Finance, 42, 689-709.

DOI: https://doi.org/10.1016/j.ribaf.2017.07.011 


\section{ENTREPRENEURSHIP AND SUSTAINABILITY ISSUES}

ISSN 2345-0282 (online) http://jssidoi.org/jesi/

2021 Volume 8 Number 4 (June)

http://doi.org/10.9770/jesi.2021.8.4(36)

Eluyela, D. F., Akintimehin, O. O., Okere, W., Ozordi, E., Osuma, G. O., Ilogho, S. O., \& Oladipo, O. A. (2018). Board meeting frequency and firm performance: examining the nexus in Nigerian deposit money banks. Heliyon, 4(10), 1-14.

DOI: https://doi.org/10.1016/j.heliyon.2018.e00850

Fosu, S. (2013). Capital structure, product market competition and firm performance: Evidence from South Africa. The quarterly review of economics and finance, 53(2), 140-151.

DOI: https://doi.org/10.1016/j.qref.2013.02.004

Garcia-Torea, N., Fernandez-Feijoo, B., \& de la Cuesta, M. (2016). Board of director's effectiveness and the stakeholder perspective of corporate governance: Do effective boards promote the interests of shareholders and stakeholders? BRQ Business Research Quarterly, 19(4), 246-260.

DOI: https://doi.org/10.1016/j.brq.2016.06.001

Gupta, P., \& Sharma, A. M. (2014). A study of the impact of corporate governance practices on firm performance in Indian and South Korean companies. Procedia-Social and Behavioral Sciences, 133, 4-11.

DOI: https://doi.org/10.1016/j.sbspro.2014.04.163

Handoo, A., \& Sharma, K. (2014). A study on determinants of capital structure in India. IIMB Management review, 26(3), $170-182$.

DOI: https://doi.org/10.1016/j.iimb.2014.07.009

Jabareen, Y. (2009). Building a conceptual framework: philosophy, definitions, and procedure. International journal of qualitative methods, 8(4), 49-62.

DOI: https://doi.org/10.1177/160940690900800406

Koop, G. (2006). Analysis of financial data. Chichester; Hoboken, NJ: John Wiley \& Sons Inc. Retrieved September 20, 2018, from http://www.microlinkcolleges.net/elib/files/undergraduate/AccountingandFinance/Gary\%20Koop-Analysis\%20of\%20Financial\%20DataJohn\%20Wiley\%20\&\%20Sons\%20Inc\%20(2006).pdf

Liu, Y., Wei, Z., \& Xie, F. (2014). Do women directors improve firm performance in China?. Journal of Corporate Finance, 28, $169-184$. DOI: https://doi.org/10.1016/j.jcorpfin.2013.11.016

Maug, E. (1997). Boards of directors and capital structure: alternative forms of corporate restructuring. Journal of Corporate Finance, 3(2), 113-139.

DOI: https://doi.org/10.1016/S0929-1199(96)00010-7

Madanoglu, M., Kizildag, M., \& Ozdemir, O. (2018). Which bundles of corporate governance provisions lead to high firm performance among restaurant firms? International Journal of Hospitality Management, 72, 98-108.

DOI: https://doi.org/10.1016/j.ijhm.2018.01.006

Modigliani, F., \& Miller, M. H. (1958). The cost of capital, corporation finance and the theory of investment. The American economic review, 48(3), 261-297. Retrieved August 5, 2018, from

http://lib.cufe.edu.cn/upload_files/other/3_20140507105115_01.pdf

Panditharathna, K., \& Kawshala, H. (2017). The Relationship between Corporate Governance and Firm Performance. Management and Administrative Sciences Review, 6(2), 73-84. Retrieved February 23, 2019, from https://www.academia.edu/32061785/The Relationship between Corporate Governance and Firm Performance

Pillai, R., \& Al-Malkawi, H. A. N. (2018). On the relationship between corporate governance and firm performance: Evidence from GCC countries. Research in International Business and Finance, 44, 394-410.

DOI: https://doi.org/10.1016/j.ribaf.2017.07.110

Ramli, N. A., Latan, H., \& Solovida, G. T. (2019). Determinants of capital structure and firm financial performance-A PLS-SEM approach: Evidence from Malaysia and Indonesia. The Quarterly Review of Economics and Finance, 71, 148-160.

DOI: https://doi.org/10.1016/j.qref.2018.07.001

Rashid, A. (2018). Board independence and firm performance: Evidence from Bangladesh. Future Business Journal, 4(1), 34-49.

DOI: https://doi.org/10.1016/j.fbj.2017.11.003 


\section{ENTREPRENEURSHIP AND SUSTAINABILITY ISSUES}

ISSN 2345-0282 (online) http://jssidoi.org/jesi/

2021 Volume 8 Number 4 (June)

http://doi.org/10.9770/jesi.2021.8.4(36)

Salim, M., \& Yadav, R. (2012). Capital structure and firm performance: Evidence from Malaysian listed companies. Procedia-Social and Behavioral Sciences, 65, 156-166.

DOI: https://doi.org/10.1016/j.sbspro.2012.11.105

Sial, M., Zheng, C., Cherian, J., Gulzar, M. A., Thu, P., Khan, T., \& Khuong, N. (2018). Does Corporate Social Responsibility Mediate the Relation between Boardroom Gender Diversity and Firm Performance of Chinese Listed Companies?. Sustainability, 10(10), 3591, 1-18. DOI: https://doi.org/10.3390/su10103591

Singh, D. (2016). A panel data analysis of capital structure determinants: An empirical study of non-financial firms in Oman. International Journal of Economics and Financial Issues, 6(4), 1650-1656. Retrieved May 13, 2019, from https://www.researchgate.net/profile/Dharmendra-Singh-

51/publication/324389002_A_Panel_Data_Analysis_of_Capital_Structure_Determinants_An_Empirical_Study_of_NonFinancial Firms in Oman/links/5acc5ba0a6fdcc8bfc87549b/A-Panel-Data-Analysis-of-Capital-Structure-Determinants-An-EmpiricalStudy-of-Non-Financial-Firms-in-Oman.pdf

Vătavu, S. (2015). The impact of capital structure on financial performance in Romanian listed companies. Procedia Economics and Finance, 32, 1314-1322.

DOI: https://doi.org/10.1016/S2212-5671(15)01508-7

Wooldridge, J. M. (2012). Introductory econometrics: A modern approach: Nelson Education. Scarborough, ON, Canada. Retrieved August 7, 2018, from

https://economics.ut.ac.ir/documents/3030266/14100645/Jeffrey M. Wooldridge Introductory Econometrics A Modern Approach 20 $\underline{12 . p d f}$

Y1lmaz, İ. (2018). Corporate Governance and Financial Performance Relationship: Case for Oman Companies. Journal of Accounting, Finance and Auditing Studies, 4(4), 84-106.

DOI: http://dx.doi.org/10.32602/jafas.2018.006

Zabri, S. M., Ahmad, K., \& Wah, K. K. (2016). Corporate governance practices and firm performance: Evidence from top 100 public listed companies in Malaysia. Procedia Economics and Finance, 35, 287-296.

DOI: https://doi.org/10.1016/S2212-5671(16)00036-8

Zeitun, R. (2014). Corporate governance, capital structure and corporate performance: evidence from GCC countries. Review of Middle East Economics and Finance Rev. Middle East Econ. Fin., 10(1), 75-96.

DOI: https://doi.org/10.1515/rmeef-2012-0028

Zhou, H., Owusu-Ansah, S., \& Maggina, A. (2018). Board of directors, audit committee, and firm performance: Evidence from Greece. Journal of International Accounting, Auditing and Taxation, 31, 20-36.

DOI: $\underline{\text { https://doi.org/10.1016/j.intaccaudtax.2018.03.002 }}$ 


\section{ENTREPRENEURSHIP AND SUSTAINABILITY ISSUES}

ISSN 2345-0282 (online) http://jssidoi.org/jesi/

2021 Volume 8 Number 4 (June)

http://doi.org/10.9770/jesi.2021.8.4(36)

Hana BAWAZIR, Head of Economics and Finance Department at the University of Bahrain and a Chairwoman of the Cultural Committee of Bahrain Economist Society. Prior to her appointment at UOB, Hana worked as an economist in the Middle East and Central Asia Division at the IMF in Washington DC. Earlier in her career, she also worked as a visiting scholar and lecturer at Southampton University. Her research interest focuses on the empirical modelling of bank behaviour. In particular, she primarily investigates the role of the government in banking systems in terms of regulation, supervision, and bank bailouts, and how such government interventions affect bank conduct. Currently she is working on the impact of financial innovation and the role of financial inclusion on the national economy by reducing government expenditures and enhancing economic growth. Dr. Bawazir holds a PhD in Banking and Finance and an MSc in Int'l Banking and Financial Studies from Southampton University, UK. Bachelor's degree in Banking and Finance from University of Bahrain.

ORCID ID: orcid.org/ 0000-0002-7158-3771

Anis KHAYATI received his Ph.D. in Economics from Nagoya City University, Japan. He has been a faculty member at different universities in the Middle East, where he taught many courses in economics and finance. He is currently an Assistant Professor in Economics at the College of Business Administration, University of Bahrain. His main research interests are in the areas of FDI, multinational firms, economic growth, technology transfer, investment decisions, educational economics and monetary economics. He published many articles in regional and international journals.

ORCID ID: orcid.org/ 0000-0002-5520-7354

Fatema ABDULMAJEED holds a degree of BSc in Banking \& Finance, 2012 from University of Bahrain, Kingdom of Bahrain. In 2020, she obtained her MBA Degree in Banking \& Finance from the same university in the Kingdom. She worked as an Accountant in private sector for a while. She has currently been working as a Purchasing Specialist in the Ministry of Interior of Bahrain.

ORCID ID: orcid.org/ 0000-0002-3408-0753

Make your research more visible, join the Twitter account of ENTREPRENEURSHIP AND SUSTAINABILITY ISSUES: @Entrepr69728810

Copyright (C) 2021 by author(s) and VsI Entrepreneurship and Sustainability Center

This work is licensed under the Creative Commons Attribution International License (CC BY).

http://creativecommons.org/licenses/by/4.0/

cc) (i) Open Access 